\title{
Mágneses anyagvizsgáló berendezés fejlesztése
}

\section{Development of magnetic material testing equipment}

\author{
Nagy András, ${ }^{1}$ Némedi Imre ${ }^{2}$ \\ ${ }^{1}$ Dunaújvárosi Egyetem, Dunaújváros, Magyarország, nagyandras@uniduna.hu \\ ${ }^{2}$ Szabadkai Müszaki Szakföiskola, Szabadka, Szerbia, nimre@vts.su.ac.rs
}

\begin{abstract}
This paper deals with the development of equipment that can accurately determine the magnetic properties of small volume thin plate samples. The alloys to be tested are sheets of amorphous structure, such as Finemet alloy, which has excellent high frequency magnetic properties, making it a good candidate for the construction of high efficiency electric motors. This article discusses the components and operation of the equipment under development, whilst giving a brief overview of the efficiency classification of electric motors and the importance of the emerging efficiency class.
\end{abstract}

Keywords: amorphous, BH curve, magnetic measuring equipment, fluxgate sensor.

\section{Összefoglalás}

Jelen cikk egy mágneses vizsgálóberendezés fejlesztési kérdéseivel foglalkozik, amely képes kis térfogatú, vékony lemez anyagminták mágneses tulajdonságainak pontos meghatározására. A vizsgálandó ötvözetek amorf szerkezetü lemezek, például Finemet-ötvözet, amelynek nagyok jók a nagyfrekvenciás mágneses tulajdonságai, így növelt hatásfokú elektromotorok építéséhez kiváló jelölt. A cikk tárgyalja a fejlesztés alatt álló berendezés részegységeit, működését, illetve rövid kitekintést nyújt az elektromotorok hatásfok szerinti osztályozásáról és a megjelenő új hatásfokosztály fontosságáról.

Kulcsszavak: amorf anyag, mágnesezési görbe, mágneses méröberendezés.

\section{Bevezetés}

A szakirodalomból látható, hogy az amorf ötvözetek alkalmazása a nagy sebességű elektromotorok állórészének építésénél jelentősen csökkenti a vasveszteséget, így növeli az elektromotor hatásfokát. [1]-ben 6 pólusú elektromotor állórészét készítették el amorf anyagból, amivel 90\% feletti hatásfokot értek el. BLDC (brushless direct current) motorokban amorf anyag alkalmazása szintén előnyös tulajdonságokat mutat, [2]-ben Metglas 2605 SA1 ötvözet felhasználásával 1 kW-os, 70000 fordulat/perc sebességű motort építettek. A tesztek igazolták, hogy amorf anyag alkalmazásával csökkenthető az elektromotor melegedése. [3] átfogó képet nyújt arról, hogy az elmúlt időszakban milyen eredménnyel alkalmazták az amorf anyagokat elektromotorokban. Egy kétpó- lusú, 1,2 kW-os motor vizsgálata során kiderült, hogy a veszteség a hagyományos anyagokhoz képest 1/5-re csökken amorf anyagok alkalmazásával [4].

Az Európai Unió rendeletet [5] fogalmazott meg az elektromotorok környezettudatos tervezési követelményeiről.

A gyártóipari szektorban a villamosenergia-felhasználás átlagosan 70\%-át az elektromotorok adják [6]. Tisztán látható tehát, hogy a cél a jobb hatásfokú energiafelhasználás, ami környezetvédelmi szempontból kevesebb károsanyag-kibocsátást jelent.

Az amorf anyagok alkalmazásának feltétele, hogy a vékony, 20-40 $\mu \mathrm{m}$ vastagságú amorf lemezeket úgy vágjuk ki a megfelelő formára, hogy a megmunkálás a lehető legkisebb hatással legyen 
az amorf szerkezetre, illetve a kedvező mágneses tulajdonságokra. A kivágási kísérletek [7] azt mutatják, hogy megfelelő technológiai paraméterekkel végzett lézeres vágás esetén minimális hőhatásövezet alakul ki. Ezzel az amorf anyagszerkezet csak olyan mértékben sérül, ami számottevően nem befolyásolja a mágneses tulajdonságokat.

Jelen cikk olyan berendezés fejlesztését mutatja be, amelynek segítségével mérhető a különböző vágási eljárások hatása az anyag mágneses tulajdonságaira. A berendezés áramköri felépítése mellett a berendezés és a mérési eljárás fejlesztése során felmerülő kérdéseket és megoldásokat ismertetjük.

\section{A berendezés felépítése}

\subsection{A berendezés müködésének alapja}

A mágneses vizsgálóberendezés működése azon alapul, hogy ha egy anyagot állandó mágneses térbe helyezünk, annak a gerjesztés hatására saját mágneses tere alakul ki. Ezt mérve meghatározható a hiszterézisgörbe, és kiszámíthatók az abból kapható értékek (pl. koercitív erő, remanens mágnesezettség stb.). A vizsgálandó minta gerjesztéséhez a homogén mágneses teret többféle módon elő lehet állítani, például Helmholtz-tekerccsel vagy szolenoiddal. Az itt bemutatott mágneses vizsgálóberendezés szolenoidot használ erre a célra, melynek belsejében (megfelelően pontos geometria esetén) nagy pontossággal előállítható mágneses tér (1. ábra).

A szolenoid belsejében elhelyezett ferromágneses minta saját mágneses teret hoz létre a gerjesztés hatására. Ez a kialakuló mágneses tér a gerjesztés miatt szintén időben állandó, így ennek mérésére a hagyományos (változó mágneses tér által indukált feszültség mérésén alapuló) mérőtekercs nem alkalmas. A megfelelő mágnesestér-szenzor kiválasztásához meg kell határozni

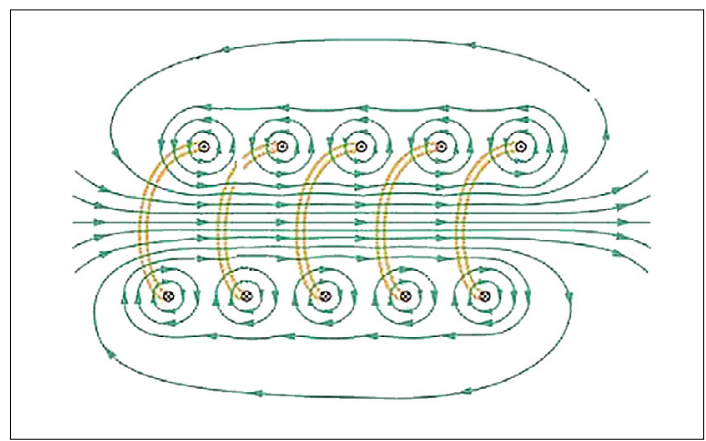

1. ábra. A szolenoid belsejében kialakuló mágneses teret szemléltető vonalak [8] néhány jellemzőt, amelyek a specifikáció alapját adják.

A 2. ábrán látható, hogyan helyezkedik el a minta a szolenoid belsejében. A szolenoid által létrehozott gerjesztő mágneses tér hatására kialakul a minta mágneses tere, amely a kis térfogatú minta miatt nagyságrendekkel gyengébb, mint a gerjesztő mágneses tér.

A mérési eljárás lényege tehát, hogy a szolenoiddal nagy pontossággal előállított gerjesztés (mágneses térerősség, H) hatására kialakuló mágneses teret (B) mérjük. Ebből a B-H görbe megrajzolható és a mágneses jellemzők számíthatók.

A mágneses vizsgálóberendezés blokkdiagramja a 3. ábrán látható.

A központi vezérlést egy 16 bites PIC-mikrovezérlő végzi, ez kommunikál a tekercsmeghajtó áramkörrel, amely lehetővé teszi a kimeneti áram digitális beállítását. A térerősségszenzorok szenzorillesztő részáramköre jelkondicionálást és -leválasztást végez, lehetővé téve a nagy felbontású digitalizálást. A berendezés digitális interfészen (USB - VCP) keresztül kommunikál a PC-re fejlesztett vezérlőszoftverrel.

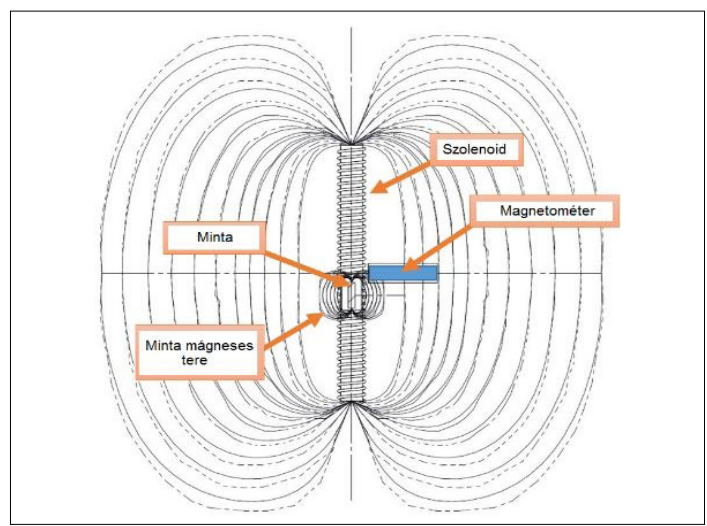

2. ábra. A szolenoid belsejébe helyezett minta mágneses tere és az annak mérésére szolgáló magnetométer elhelyezése

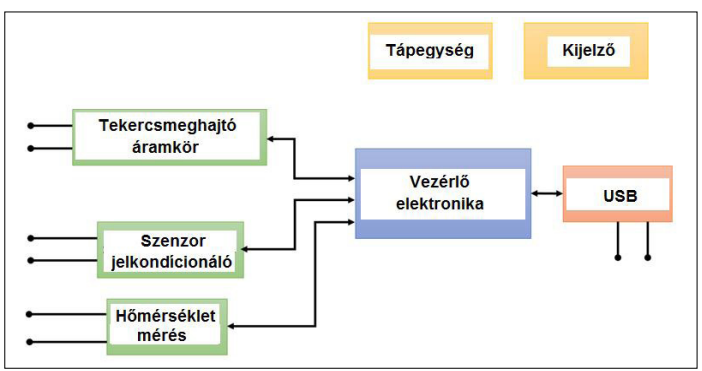

3. ábra. A mágneses vizsgálóberendezés elektronikájának blokkdiagramja 


\subsection{A szolenoid méretezése}

A berendezés egyik fő alkotóeleme a homogén mágneses teret előállító szolenoid. Az ennek belsejében kialakuló térerősség mértéke az alábbi képlettel számítható ki:

$$
\mathrm{H}=(\mathrm{N} \cdot \mathrm{I}) / \mathrm{L}
$$

ahol

$\mathrm{H}$ - mágneses térerősség, $\mathrm{A} / \mathrm{m}$;

$\mathrm{N}$ - szolenoid menetszáma;

I - szolenoidban folyó villamos áramerősség, A;

L - szolenoid hossza, m.

Látható, hogy adott geometria esetén a térerősség a tekercsben folyó árammal arányosan változtatható, lineáris összefüggés szerint. A szolenoid méretezéséhez további összefüggéseket is felhasználtunk, mint például az Ohm-törvényt.

A méretezés néhány rögzített adatból indult ki:

- szolenoid hossza: $500 \mathrm{~mm}$;

- szolenoid csévetest külső átmérője: 50 mm;

- maximális mágneses térerősség (min.): $30000 \mathrm{~A} / \mathrm{m}$.

A kiinduló adatokból az alábbi eredmények adódtak:

- szolenoid menetszáma (rétegenként): 306;

- rétegek száma: 6;

- szolenoid ohmikus ellenállása: 3,08 $\Omega$;

- maximális tekercsáram: 10,3 A;

- tekercs teljesítménydisszipáció: 332 W;

- tekercselőhuzal átmérője: 1,6 mm.

A tekercs által disszipált teljesítmény hővé alakul, amely melegíti a tekercset, növelve annak ellenállását. A pontos térerősség beállítása érdekében áramgenerátoros meghajtója van a berendezésnek, amely a tekercs ellenállásától függetlenül állandó áramot hajt át a tekercsen. A szolenoid terve és a megépült egység a 4 . ábrán látható.

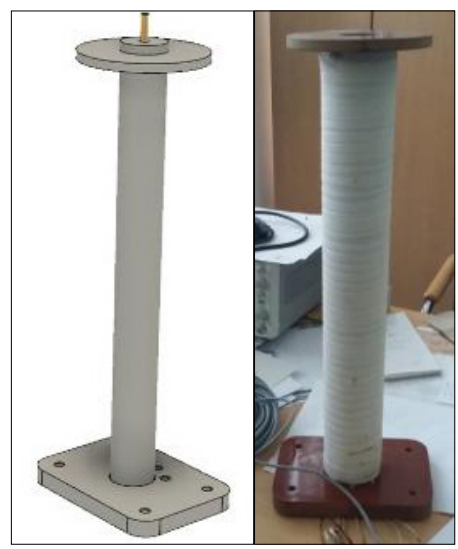

4. ábra. A berendezés szolenoidjának terve és a megépült szolenoid

\subsection{A mágnesestér-érzékelő}

A gerjesztett minta saját mágneses terének érzékeléséhez körültekintően választott szenzorra van szükség. Az 5. ábra néhány magnetométer-fajtát hasonlít össze a mérési tartomány alapján.

A szenzorral szemben támasztott követelmények közül kiemelhető a viszonylag nagy érzékenység $( \pm 10 \mu \mathrm{T})$, a nagyfokú irányérzékenység, illetve az, hogy képes legyen állandó mágneses tér érzékelésére is.

Ezen követelményeknek a fluxgate típusú szenzorok felelnek meg a legjobban.

A fluxgate magnetométer müködési elvét a 6. ábra szemlélteti. Az (a) ábrán látható ferromágneses vasmagot a meghajtó (elsődleges) tekercs pozitív és negatív irányban is telítésbe viszi, periodikusan. A fluxsűrűség-változás az érzékelő (másodlagos) tekerccsel fogható fel. Külső mágneses tér jelenlétében ez a jel aszimmetrikussá válik, a mágneses térerősség arányos a jel második harmonikusával, lásd a (b) ábrát.

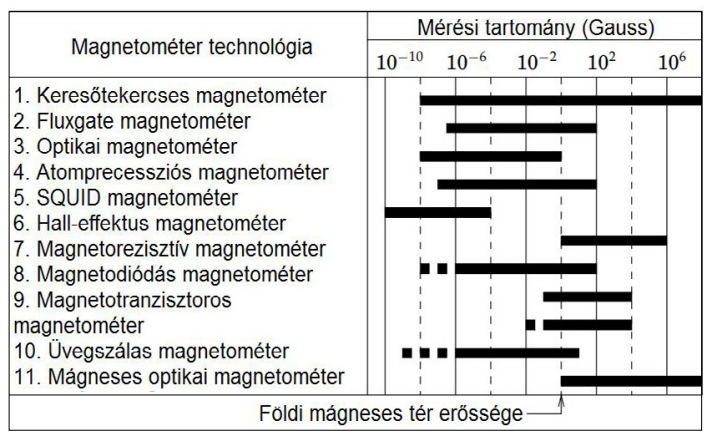

5. ábra. Magnetométer-technológiák összehasonlítása mérési tartomány alapján [9]

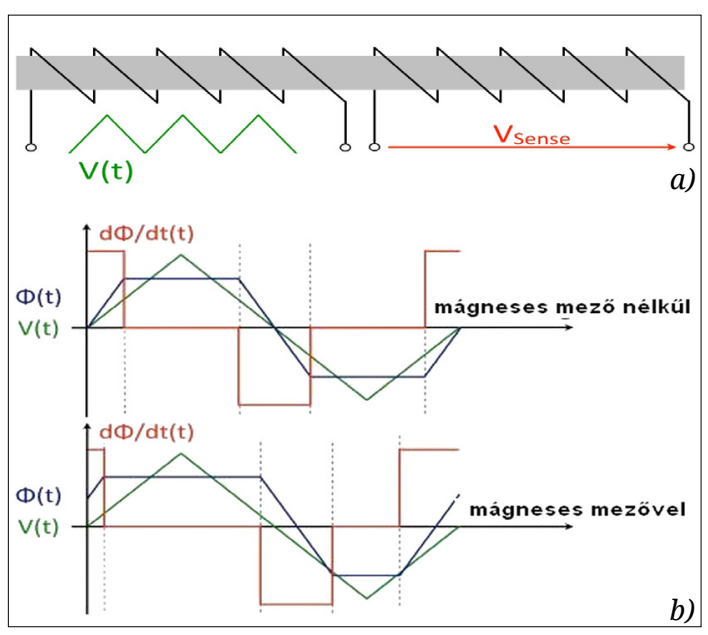

6. ábra. A fluxgate magnetométer múködési elve [10] 


\section{A részegységek tervezése}

\subsection{Tekercsmeghajtó elektronika}

A tekercsmeghajtó áramkör alapjában véve egy áramgenerátor és egy dupla $\mathrm{H}$ híd egybeépítve. Ezzel a megoldással az áram irányát és nagyságát egyszerre lehet változtatni. A dupla $\mathrm{H}$ híd az áramirányváltás mellett a mérési tartomány átkapcsolását is lehetővé teszi, így nagyobb és kisebb térfogatú minták is pontosan vizsgálhatók.

Az elkészült elektronikáról a 7. ábrán látható fotó, a 8. ábra pedig a különböző szintű terveket mutatja.

\subsection{A tápegység-elektronika}

A tápegységnek több stabilizált feszültségszintet elő kell állítania, többek között 5 V-ot a digitális áramköröknek, \pm 12 V-ot a fluxgate szenzornak, 36 V-ot a szolenoidmeghajtáshoz. Az áramköri rajz, a NYÁK-terv és a 3D-s modell a 9. ábrán látható.

A tápegység 230/36 V-os toroidtranszformátor által előállított feszültséget használ, így a hálózati leválasztás, az érintésvédelem biztosítva van. $\mathrm{Az}$ elkészült tápegységről készített fénykép a 10. ábrán látható.

\subsection{Mérésvezérlő és kommunikációs egység}

A mérési folyamat vezérléséhez és az analóg jelek digitalizálásához, valamint a mért értékek számítógépbe juttatásához külön mérésvezérlő modul készült. A rendszer lelke egy 16 bites PIC-mikrovezérlő, a dsPIC30F6014A-30 típus.

A 11. ábra az egység kapcsolási rajzát, a NYÁK tervét és a 3D-s modelljét szemlélteti. Az egység egy 4 soros LCD-kijelzőt is kapott, amely segítségével a mérési folyamatról lehet tájékoztatni a felhasználót. A 12. ábrán az egység az előlappal öszszeépítve látható, a csatlakozó szalagkábelekkel.

A mérésvezérlő egység tervezése során meg kellett oldani az USB-port galvanikus leválasztását, így sem a számítógép, sem az egység nem károsodik hot-plug esemény hatására, illetve nem tud kialakulni földhurok. Ez egy $6 \mathrm{kV}$-os, izolációs feszültségű elválasztóval valósult meg, az UART RX és TX vonalainak megszakításával. Az USB-kommunikáció virtuális soros porton (VCP) zajlik, egy MCP 2200 integrált áramkör alkalmazásával. Ezt a PC USB-portjától kapott feszültség táplálja, így független az egység állapotától.

\section{4. Összefoglalás}

Jelen cikk a Dunaújvárosi Egyetemen fejlesztés alatt álló mágneses vizsgálóberendezés fejleszté-

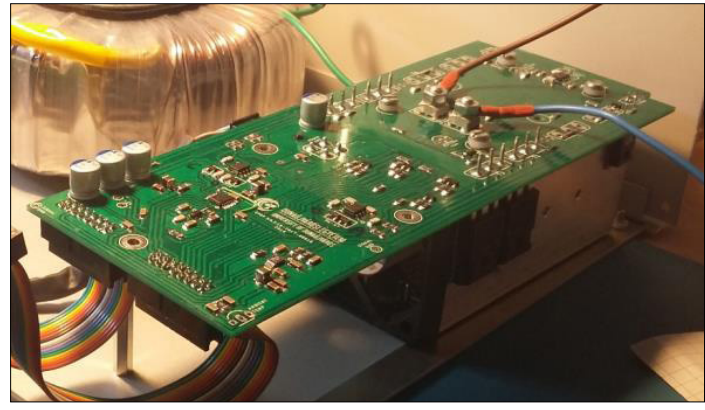

7. ábra. A legyártott és beépített tekercsmeghajtó elektronika

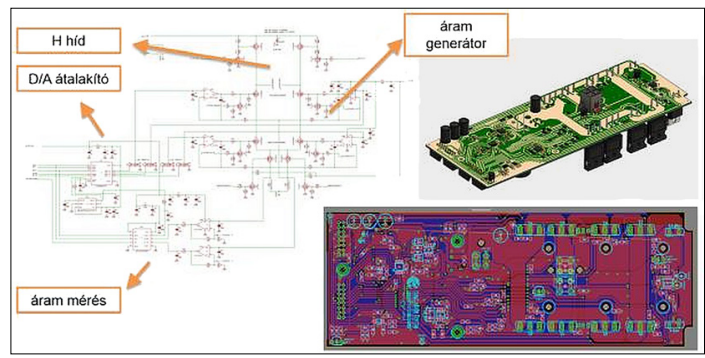

8. ábra. A tekercsmeghajtó elektronika kapcsolási rajza, NYÁK-terve és $3 D$-s modellje

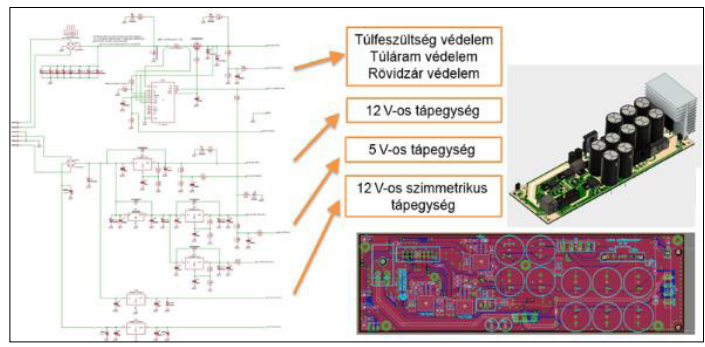

9. ábra. A tápegység kapcsolási rajza, NYÁK-terve és $3 D$-s modellje

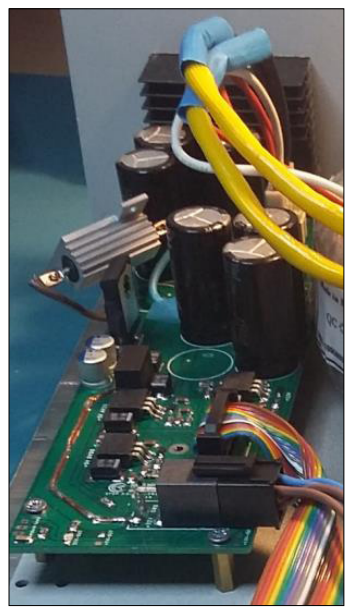

10. ábra. A tápegység legyártva és beépítve 


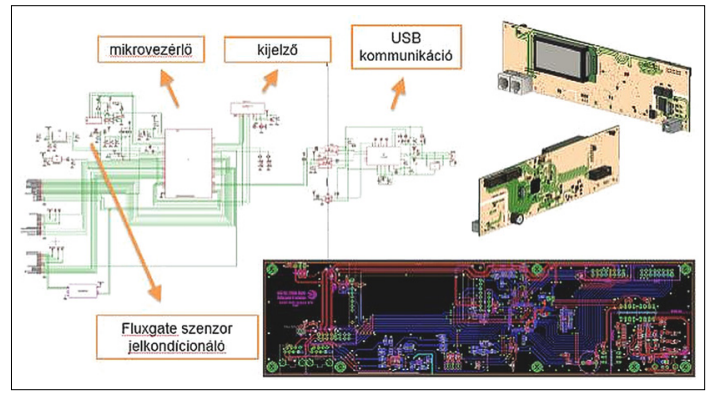

11. ábra. A mérésvezérlő kapcsolási rajza, NYÁK-terve és $3 D$-s modellje

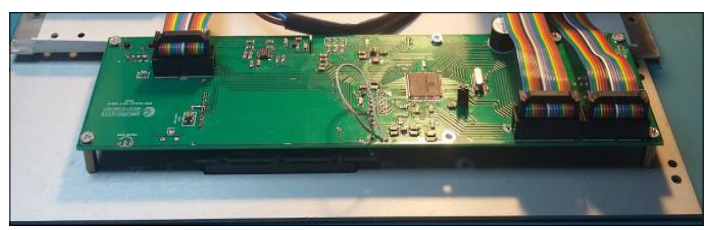

12. ábra. A mérésvezérlő legyártott és beépített állapotban

sét mutatta be. A berendezés képes kis térfogatú ferromágneses anyagminták hiszterézisgörbéjének méréssel történő meghatározására, szolenoid belsejében előállított homogén, stacioner mágneses tér $(\mathrm{H})$ alkalmazásával. A minta mágneses terének (B) mérésére fluxgate szenzort alkalmaztunk. A fő egységek: szolenoid, szolenoidmeghajtó egység, központi mérésvezérlő egység, tápegység, valamint a PC oldali szoftver. A berendezés fejlesztés alatt van, hamarosan kalibrálási eredmények is rendelkezésre állnak.

A berendezés fejlesztése szorosan kapcsolódik az elektromotorok hatásfokát javító kutatásokhoz, amelyek többek között a vasveszteség csökkentését célozzák meg amorf anyagok alkalmazásával. Ezen anyagok pontos formázási/kivágási technológiájának kidolgozása elengedhetetlen ahhoz, hogy elektromotorok építésére lehessen ezeket alkalmazni. A vágás technológiai paramétereit úgy kell meghatározni, hogy a művelet a lehető legkevésbé rontsa az alapanyag kiváló mágneses tulajdonságait.

\section{Köszönetnyilvánítás}

A dolgozatban bemutatott kutatást az Új Széchenyi Terv keretében az EFOP-3.6.2-16-2017-00016 projekt részeként hajtották végre. A jelen cikkben megjelenített eredményekhez az EFOP-3.6.1-16-2016-00003 $\mathrm{K}+\mathrm{F}+\mathrm{I}$ folyamatok hosszú távú megerősítése a Dunaújvárosi Egyetemen c. projekt által finanszírozott kutatások járultak hozzá. A projekt befejezését az
Európai Unió és az Európai Szociális Alap társfinanszírozza.

\section{Szakirodalmi hivatkozások}

[1] Wang Z. et al.: Development of an Axial Gap Motor With Amorphous Metal Cores. IEEE Transactions on Industry Applications, 47/3. (2011) 1293-1299. https://doi.org/10.1109/TIA.2011.2127430

[2] Kolano R., Krykowski K., Kolano-Burian A., Polak M., Szynowski J., Zackiewicz P.: Amorphous Soft Magnetic Materials for the Stator of a Novel HighSpeed PMBLDC Motor. IEEE Transactions on Magnetics, 49/4. (2013) 1367-1371. https://doi.org/10.1109/TMAG.2012.2234757

[3] Krings A., Boglietti A., Cavagnino A., Sprague S.: Soft Magnetic Material Status and Trends in Electric Machines. IEEE Transactions on Industrial Electronics, 64/3. (2017) 2405-2414, March. https://doi.org/10.1109/TIE.2016.2613844

[4] Yang W., Huang C., Zhang Q.: Optimization of Squirrel-Cage Rotor for Amorphous Asynchronous Motor. Chinese Automation Congress (CAC), Hangzhou, China, 2019, 2107-2110.

[5] A BIZOTTSÁG (EU) 2019/1781. rendelete (2019. október 1.) az elektromos motorokra és a frekvenciaváltókra vonatkozó környezettudatos tervezési követelményeknek a 2009/125/EK európai parlamenti és tanácsi irányelv szerinti megállapításáról, a 641/2009/EK rendeletnek a tömszelence nélküli önálló keringetőszivattyúkra és a termékbe beépített tömszelence nélküli keringetőszivattyúkra vonatkozó környezettudatos tervezési követelmények tekintetében történő módosításáról és a 640/2009/EK bizottsági rendelet hatályon kívül helyezéséről

[6] Global Efficiency Intelligence LLC.: Global Industrial Motor Systems Efficiency Initiative.

https://www.globalefficiencyintel.com/global-industrial-motor-systems-initiative, January, 2020

[7] Szabo A., Koti D., Santa O., Kozsely G.: Development of the Shaping Method of Amorphous Ribbons Used in Electric Drives. XXXVI. International Colloquium Advanced Manufacturing and Repair Technologies in Vehicle Industry, Vol. XIX, 2019.

[8] Waide P., Brunner C.: Energy-Efficiency Policy Opportunities for Electric Motor-Driven Systems. IEA Energy Papers, 7. (2011), OECD Publishing, https://doi.org/10.1787/5kgg52gb9gjd-en

[9] Sheiretov Y.: Deep Penetration Magnetoquasistatic Sensors. Doctor of Philosophy at the Massachusetts Institute of Technology, June 2001

[10] Dirk Ettelt.: Conception et fabrication d'un magnétomètre à jauge de contrainte. Université de Grenoble, 2012, French, https://tel.archives-ouvertes.fr/tel-00744722 